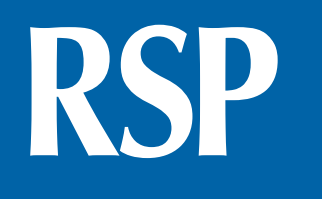

http://www.rsp.fsp.usp.br/
Revista de Saúde Pública

\title{
Vectors of arboviruses in the state of São Paulo: 30 years of Aedes aegypti and Aedes albopictus
}

\author{
Dalton Pereira da Fonseca Júnior' ${ }^{1}$, Lígia Leandro Nunes Serpa' iD, Gerson Laurindo \\ Barbosa' iD, Mariza Pereira' (iD, Marcia Moreira Holcmam' iD, Júlio Cesar Voltolini" (iD, Gisela \\ Rita Alvarenga Monteiro Marques' iD \\ I Superintendência de Controle de Endemias. Departamento de Controle de Vetores. São Paulo, SP, Brasil \\ " Universidade de Taubaté. Faculdade de Ciências Biológicas. Taubaté, SP, Brasil
}

\section{ABSTRACT}

OBJECTIVE: To describe the infestation of the municipalities of São Paulo by the vectors Aedes aegypti and Aedes albopictus, characterize seasonality and analyze average temperatures and larval densities.

METHODS: We used maps with information on the infestation of municipalities between 1986 and 2015. The analysis of larval density of the species by the Wilcoxon test used the Breteau index values for Ae. aegypti and Ae. albopictus obtained from the Superintendency for Endemic Diseases Control database. In the seasonal description, arithmetic means of each vector were calculated by month and year. Mean temperature analyses were presented on maps with color gradients.

RESULTS: The state of São Paulo is currently almost totally infested, with co-occurrence of species in $93.64 \%$ of the municipalities. The seasonality analysis showed the first quarter as the most favorable period for larval abundance. The increase of mean temperatures in geographical areas coincided with the temporal trajectory of Ae. aegypti territorial expansion. The mean larval density found was higher for Ae. aegypti than for Ae. albopictus ( $\mathrm{p}=0.00)$.

Dalton Pereira da Fonseca Júnior Superintendência de Controle de Endemias - Sucen

Rua Paula Souza, 166

01027-000 São Paulo, SP, Brasil

E-mail: dalton@sucen.sp.gov.br

Received: Oct 10, 2018

Approved: Jan 27, 2019

How to cite: : Fonseca Júnior DP, Serpa LLN, Barbosa GL, Pereira M, Holcmam MM, Voltolini JC, et al. Vectors of arboviruses in the state of São Paulo: 30 years of Aedes aegypti and Aedes albopictus. Rev Saude Publica. 2019;53:84

Copyright: This is an open-access article distributed under the terms of the Creative Commons Attribution License, which permits unrestricted use, distribution, and reproduction in any medium, provided that the original author and source are credited.

CONCLUSIONS: Initially, these Culicidae occupied distinct and opposing areas. Over time, however, co-occurrence showed how great their capacity for adaptation is, even in the face of different social and urban conjunctures. The increase of the mean temperature contributed to Ae. Aegyptis geographic expansion, as well as to the clearly seasonal profile of both species. In general, larval infestation by Ae. aegypti prevailed, which evidenced its competitive superiority. These data provide a better understanding of the dynamics of arboviral transmission in the state of São Paulo and can be used in vector surveillance and control.

DESCRITORES: Aedes. Mosquitos Vetores. Vetores de Doenças. Análise Espacial. Controle de Vetores. 


\section{INTRODUCTION}

Aedes (Stegomyia) aegypti and Aedes (Stegomyia) albopictus are major vectors of viruses that cause emerging and reemerging diseases, such as dengue, Zika, chikungunya and yellow fever, and have a wide geographical distribution. The geographic spread of these mosquitoes in the world is influenced by different factors and has been accompanied, in some places, by decrease in their abundance, elimination of the other vector, or coexistence in extensive regions of America ${ }^{1}$. In Brazil, these species were introduced at different times: Ae. aegypti in the colonization period and Ae. albopictus at the end of the 20th century ${ }^{2,3}$.

In the state of São Paulo (SP) in the early 1980s, the presence of Ae. Aegypti was detected in the port region of Santos. Five years later, an extensive entomological survey identified household infestation in nine municipalities, all located in the northwest region of the state $^{3,4}$. In 1987, outbreaks of Ae. albopictus were recorded in the eastern region of SP5. The detection of these species triggered specific control actions; however, efforts remain focused in an attempt to keep the infestation rates of these vectors low ${ }^{6}$.

The spread of these mosquitoes was probably favored by the increased circulation of people and the intensification of commercial activities, factors that aggravate the risk of arboviruses, even in hitherto unaffected regions? ${ }^{7}$. This picture may have been further intensified by the effect of climate change, which in turn impacts on the distribution of these transmitters ${ }^{8}$.

The presence of these mosquitoes in São Paulo municipalities has been identified in recent years in a growing and accelerated way, a profile that poses difficulties for the programs and actions to control these vectors. This reinforces the importance of entomological research, which can help define the spatial boundaries of the transmission of various arboviruses and better understand their ecological and occupation processes in the territorial space over time. Thus, knowledge of the spatio-temporal distribution and abundance of these vectors is an important objective of entomological surveillance, since it allows monitoring their population behavior, essential for planning public health actions. Accordingly, we here intended to describe Ae. aegypti and Ae. Albopictus in São Paulo municipalities, assuming that their population densities are different.

\section{METHODS}

This is a descriptive and retrospective study of the infestation of the state of São Paulo by Ae. aegypti and Ae. albopictus from 1986 to 2015. The study area is the most populous state of the federation, with approximately 44.85 million residents and a population density of 168 inhabitants per square $\mathrm{km}$. Located in the Southeastern region of the country, it borders the states of Paraná, Mato Grosso do Sul, Minas Gerais and Rio de Janeiro. It is one of the most important development poles of the Southern Hemisphere, representing $3 \%$ of the Brazilian surface, although its economic influence far exceeds its territorial limits. The climate classification covers seven types, with humid climate prevailing. The dominant type is characterized by the tropical climate of altitude, with rains in the summer, drought in the winter, average annual temperature of $20^{\circ} \mathrm{C}$ to $22^{\circ} \mathrm{C}$, and average temperature of the hottest month above $22^{\circ} \mathrm{C}^{10}$.

The geographic space of São Paulo has undergone, over the last years, socioeconomic transformations accompanied by an intense process of redistribution of the human population, which resulted in a regionally differentiated concentration ${ }^{11}$. The entomological indicator analyzed was the Breteau index (BI), adopted to follow the surveillance and control activities, which allows to obtain levels of larval infestation by Ae. Aegypti and Ae. albopictus for each municipality ${ }^{6-12}$.

$\mathrm{BI}=$ number of positive containers for the presence of species $\mathrm{x} 100$ No. of properties searched 
The data were obtained from the online information system of the Superintendency for Endemic Diseases Control (SUCEN), shared by the state and its municipalities. BI values measure the breeding sites by counting the containers with larvae of each species in groups of 100 surveyed properties. The value indicates the intensity of household infestation, which allows to estimate the density.

The description of the infested municipalities for each species, in time and space, was presented in annual maps. Infested municipality is one in which the species is established, that is, present even after controlling actions, with records of its development and reproduction, harboring in its extension immature forms of these vectors ${ }^{3}$.

To characterize seasonality and analyze population densities, we calculated the arithmetic means of BI values of each species by month and year of the study period. The data were analyzed using the Bioestat 5.3 software, and compared by the Wilcoxon matched pairs test or Wilcoxon signed-ranks test. Values of $p<0.05$ were considered significant.

The mean temperatures in the state of São Paulo were analyzed from data from the meteorological stations of the Meteorological Database for Teaching and Research of the Instituto Nacional de Meteorologia (National Meteorological Institute ${ }^{13}$ ). The data are presented on maps for the years 1986, 1990, 1995, 2000, 2005, 2010 and 2015. The colors represent the different temperature gradients, with the highest indicated by the dark red tone and the lowest by the lighter tone.

\section{RESULTS}

The historical series of 30 years of infestation of the municipalities of São Paulo by Ae. aegypti or Ae. albopictus is shown in Table 1. Between 1986 and 1996, the number of municipalities increased from 572 to 645 , a figure that remains to the present day.

Infestation by Ae. aegypti started in 1986, while by Ae. Albopictus in 1987, in distinct and opposing geographic areas. In the first year, the dispersion of these Aedes reached, respectively, $133(23.25 \%)$ and $6(1.05 \%)$ of the municipalities existing at the time. In the following years, the number of municipalities infested by one or the other species increased, with a higher spread and growth of Ae. aegypti than of Ae. albopictus. The number of municipalities infested in the first half of the study (1986 to 2000) was greater than in the second half. In 1994, the infestation reached the level of 91.05\%. In the last year of the study, 2015, almost the entire territory of São Paulo (99.69\%) was infested.

The co-occurrence of these Stegomyia, that is, mixed infestation, was found in six municipalities in 1989, rising to $37.05 \%$ in 1994 , at which time the number of municipalities infested exclusively by Ae. albopictus also increased, but in a geographical area other than that occupied by Ae. aegypti. Although mixed infestation has changed over time and from region to region, it began to dominate the state's geographic space and was reported in 604 (93.64\%) of the existing municipalities. Of the 41 remaining municipalities, 35 are still exclusively infested by Ae. aegypti and six by Ae. albopictus. Located in different geographic areas, the municipalities infested by Ae. aegypti were in the midwest of São Paulo, while those infested by Ae. Albopictus were in the Greater São Paulo and Paraíba Valley region. Only the municipalities of Campos do Jordão, in the Paraíba Valley region, and Ribeirão Grande, in the Sorocaba region, did not register infestation by these species.

Figure 1 shows the geographical trajectory of this infestation. It is seen that the occupation did not take place homogeneously in time and space, but there was a rapid geographic expansion. In the first year, 1986, Ae. aegypti is established in the northwest region, upper half of the state. In the following year, 1987, Ae. Albopictus was first recorded in municipalities located on the banks of the Presidente Dutra highway (BR-116), in 
Table 1. Distribution of the number of municipalities infested by Ae. aegypti or Ae. Albopictus. State of São Paulo, Brazil, 1986-2015

\begin{tabular}{|c|c|c|c|c|c|c|}
\hline \multicolumn{7}{|c|}{ Número de municípios } \\
\hline Year & Existing & $\begin{array}{l}\text { Infested by } \\
\text { Ae. aegypti }\end{array}$ & $\begin{array}{l}\text { Infested by } \\
\text { Ae. albopictus }\end{array}$ & $\begin{array}{c}\text { Mixed } \\
\text { infestation* }\end{array}$ & Total infested & $\%$ with infestation \\
\hline 1986 & 572 & 65 & 0 & 0 & 65 & 11.36 \\
\hline 1987 & 572 & 133 & 6 & 0 & 139 & 24.30 \\
\hline 1988 & 572 & 186 & 19 & 0 & 205 & 35.84 \\
\hline 1989 & 572 & 227 & 23 & 6 & 256 & 44.76 \\
\hline 1990 & 572 & 257 & 38 & 35 & 330 & 57.69 \\
\hline 1991 & 582 & 282 & 48 & 48 & 378 & 64.95 \\
\hline 1992 & 625 & 262 & 91 & 88 & 441 & 70.56 \\
\hline 1993 & 625 & 227 & 147 & 159 & 533 & 85.28 \\
\hline 1994 & 637 & 170 & 174 & 236 & 580 & 91.05 \\
\hline 1995 & 637 & 162 & 178 & 255 & 595 & 93.41 \\
\hline 1996 & 645 & 105 & 179 & 321 & 605 & 93.80 \\
\hline 1997 & 645 & 77 & 182 & 368 & 627 & 97.21 \\
\hline 1998 & 645 & 74 & 165 & 389 & 628 & 97.36 \\
\hline 1999 & 645 & 73 & 154 & 401 & 628 & 97.36 \\
\hline 2000 & 645 & 72 & 150 & 406 & 628 & 97.36 \\
\hline 2001 & 645 & 72 & 142 & 414 & 628 & 97.36 \\
\hline 2002 & 645 & 48 & 132 & 450 & 630 & 97.67 \\
\hline 2003 & 645 & 42 & 126 & 462 & 630 & 97.67 \\
\hline 2004 & 645 & 40 & 124 & 466 & 630 & 97.67 \\
\hline 2005 & 645 & 40 & 117 & 473 & 630 & 97.67 \\
\hline 2006 & 645 & 40 & 107 & 483 & 630 & 97.67 \\
\hline 2007 & 645 & 39 & 96 & 495 & 630 & 97.67 \\
\hline 2008 & 645 & 39 & 87 & 504 & 630 & 97.67 \\
\hline 2009 & 645 & 37 & 74 & 519 & 630 & 97.67 \\
\hline 2010 & 645 & 37 & 59 & 535 & 631 & 97.83 \\
\hline 2011 & 645 & 39 & 36 & 566 & 641 & 99.38 \\
\hline 2012 & 645 & 38 & 34 & 569 & 641 & 99.38 \\
\hline 2013 & 645 & 38 & 22 & 581 & 641 & 99.38 \\
\hline 2014 & 645 & 36 & 14 & 591 & 641 & 99.38 \\
\hline 2015 & 645 & 35 & 4 & 604 & 643 & 99.69 \\
\hline
\end{tabular}

*Infested by both species.

the RJ-SP direction. This area is called Vale do Paraíba (Paraíba Valley), in the eastern region of SP, opposite to that occupied by Ae. aegypti. In the sequence, in 1988, that species was established in a few municipalities in the northeastern part of the state. The co-occurrence of these species was recorded in the north-northeast region, until then occupied only by Ae.albopictus.

In the years that followed, there was a great expansion of the infested area, so that in the first half of the 1990s, three patterns in the geographical expansion of these species could be differentiated. Further to the northwest of the state, the infestation occurred by Ae. Aegypti; to the south-southeast, by Ae. albopictus; and in the northeast to southwest direction, a central band, with mixed infestation.

Chronologically, co-occurrence advanced faster in the northwest-west direction than in the south-southeast region, hitherto occupied only by Ae. albopictus. This picture did not last long, and from 2001 on Ae. aegypti has spread through most of the Paraíba Valley region, the last of the state to be infested by this species. As can be seen, in 2015, few municipalities remained free from the co-occurrence of the two species. 

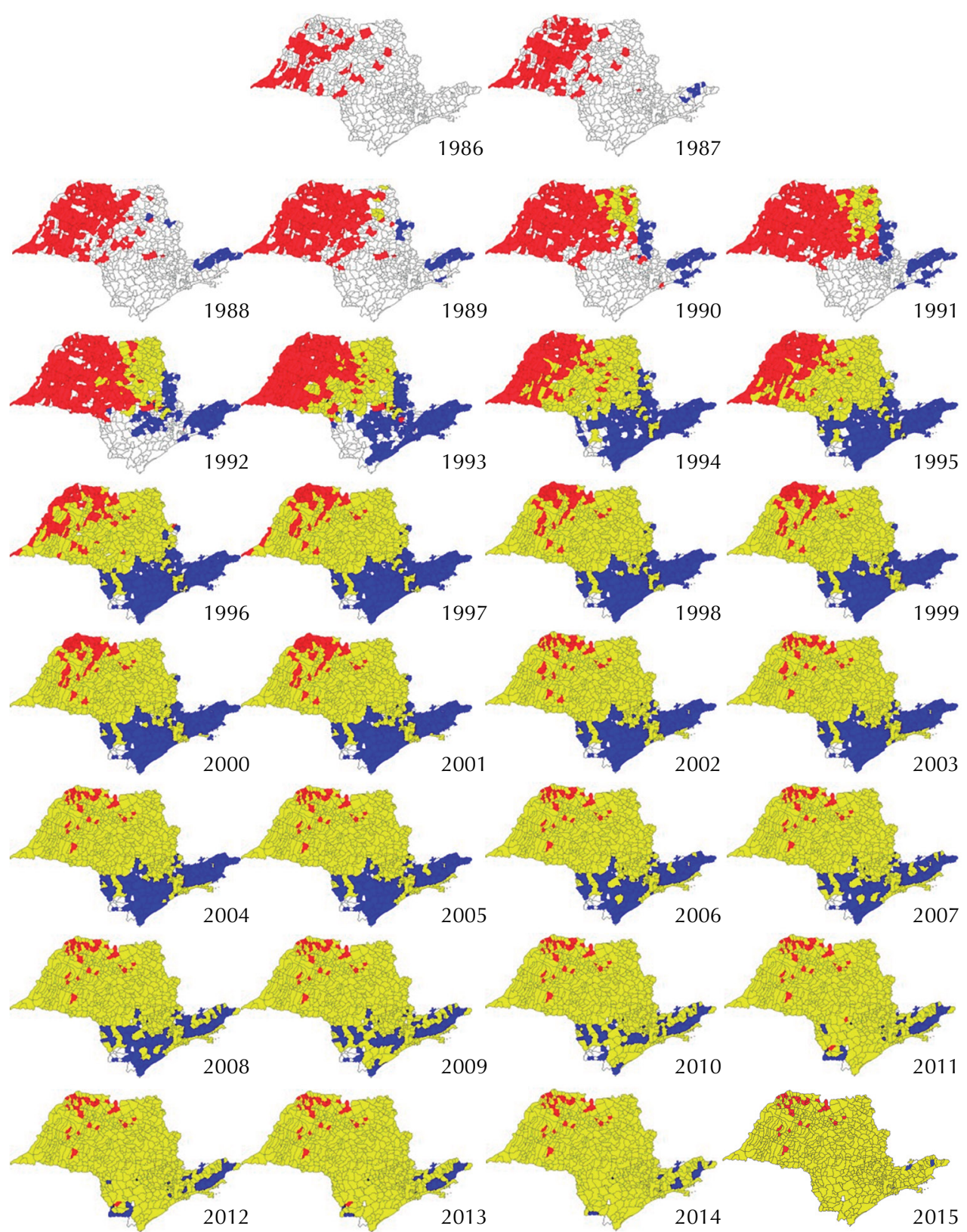

Ae. aegypti

Ae. albopictus

both species

no infestation

Figure 1. Municipalities infested by Ae. aegypti, by Ae. albopictus and by both species. State of São Paulo, 1986-2015.

Figure 2 shows the mean monthly BI values for Ae. aegypti and Ae. albopictus over 30 years of survey. A similar seasonal behavior is observed, but with different larval density values. Although with different frequencies, there are records of both species in every month of the year. The results showed that vectors most abounded in the first trimester, summer months (January to March). In the second quarter (April to June), the density indexes of both species fell, and from July to October Ae. albopictus shows quite reduced values. On the other hand, Ae. aegypti reduced its density until August (BI values close to 1.0), but resumed its population growth in the other months of the year (October to December), with average rates close to 3.0 .

Figure 3 shows the profile of the mean temperature in degree Celsius $\left({ }^{\circ} \mathrm{C}\right)$ for the state of São Paulo. The seven maps show the chronological sequence of expansion of the geographic range with higher mean temperatures. Note that this elevation is growing over the years, 


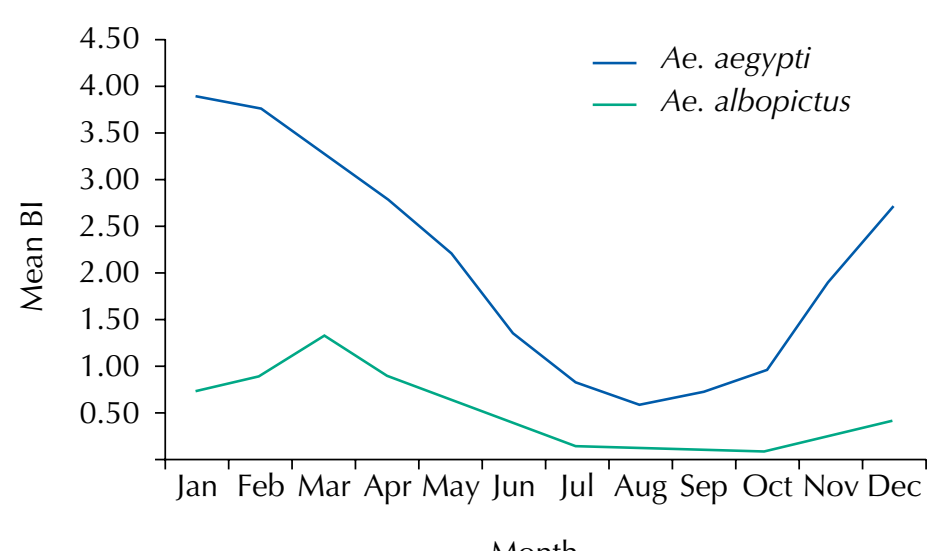

Month

Figure 2. Monthly distribution of the Breteau index (BI) mean values for Ae. Aegypti and Ae. Albopictus. State of São Paulo, 1986-2015.

moving to the interior of the state, from the plateau alignment, and to the coast, near the sierras of Paranapiacaba, do Mar and da Mantiqueira.

Table 2 shows the mean BI values. Notice that they varied according to year and species; however, Ae. aegypti indicators were always higher than those for Ae. albopictus. During the study period, 416 larval density evaluations were performed per year in average, as a result of 26,910,205 households surveyed.

The mean BI of the 30 years of study was 2.05 , with standard error $(\mathrm{SE})=0.16$, and 0.48 $(\mathrm{SD}=0.11)$ for Ae. aegypti and Ae. albopictus, respectively. Of the total number of containers surveyed, the presence of the first and second species was recorded in $83.54 \%$ and $16.46 \%$, respectively. The comparison of Ae. Aegypti and Ae. Albopictus mean BI values showed a significant statistical difference $(\mathrm{n}=30, \mathrm{~T}=0.00, \mathrm{Z}=4.78, \mathrm{p}<0.001)$, indicating that the mean larval density was significantly higher for the former than for the latter, 4.27 times as high, translating into the greater percentage of positive containers for the presence of immature forms of Ae. aegypti.

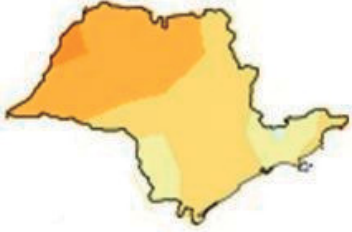

1990

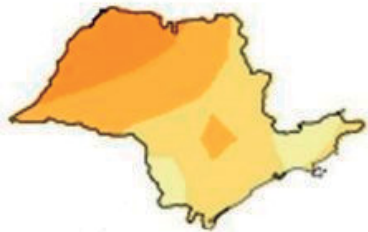

2005
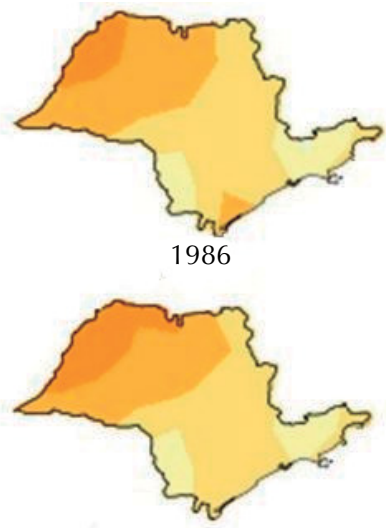

1995

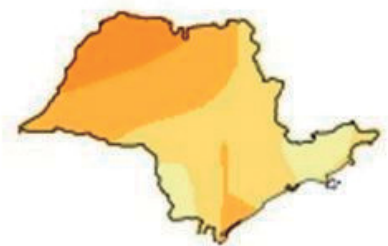

2010

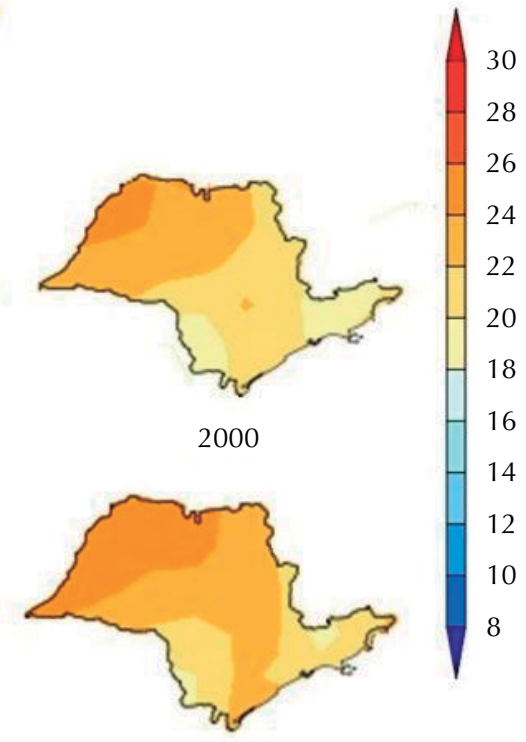

2015

Figure 3. Average temperature profile by year. State of São Paulo, Brazil, 1986, 1990, 1995, 2000, 2005, 2010 and 2015. 
Table 2. Annual distribution of the Breteau index $(\mathrm{BI})$ mean values and percentage of containers with each species. State of São Paulo, Brazil, 1986-2015

\begin{tabular}{|c|c|c|c|c|c|}
\hline Year & $\begin{array}{c}\text { BI } \\
\text { Ae. aegypti }\end{array}$ & $\begin{array}{c}\text { BI } \\
\text { Ae. albopictus }\end{array}$ & $\begin{array}{c}\text { BI } \\
\text { total }\end{array}$ & $\begin{array}{c}\% \text { of containers with } \\
\text { Ae. aegypti }\end{array}$ & $\begin{array}{c}\% \text { of containers with } \\
\text { Ae. albopictus }\end{array}$ \\
\hline 1986 & 2.28 & 0.01 & 2.29 & 99.56 & 0.44 \\
\hline 1987 & 2.18 & 0.01 & 2.19 & 99.54 & 0.46 \\
\hline 1988 & 2.73 & 0.19 & 2.92 & 93.52 & 6.48 \\
\hline 1989 & 2.96 & 0.10 & 3.06 & 96.68 & 3.32 \\
\hline 1990 & 3.60 & 0.19 & 3.79 & 94.98 & 5.02 \\
\hline 1991 & 1.84 & 0.21 & 2.05 & 89.59 & 10.41 \\
\hline 1992 & 2.35 & 0.44 & 2.79 & 84.20 & 15.80 \\
\hline 1993 & 2.76 & 0.02 & 2.79 & 99.18 & 0.82 \\
\hline 1994 & 2.40 & 1.61 & 4.02 & 59.87 & 40.13 \\
\hline 1995 & 2.30 & 1.55 & 3.85 & 59.77 & 40.23 \\
\hline 1996 & 3.68 & 1.38 & 5.07 & 72.68 & 27.32 \\
\hline 1997 & 3.17 & 1.03 & 4.20 & 75.48 & 24.52 \\
\hline 1998 & 3.42 & 1.42 & 4.83 & 70.72 & 29.28 \\
\hline 1999 & 2.39 & 0.91 & 3.30 & 72.52 & 27.48 \\
\hline 2000 & 3.43 & 1.53 & 4.96 & 69.25 & 30.75 \\
\hline 2001 & 2.34 & 0.97 & 3.31 & 70.71 & 29.29 \\
\hline 2002 & 1.15 & 0.45 & 1.60 & 72.14 & 27.86 \\
\hline 2003 & 1.23 & 0.39 & 1.62 & 75.96 & 24.04 \\
\hline 2004 & 1.54 & 0.40 & 1.95 & 79.28 & 20.72 \\
\hline 2005 & 1.98 & 0.33 & 2.30 & 85.81 & 14.19 \\
\hline 2006 & 1.59 & 0.22 & 1.80 & 87.96 & 12.04 \\
\hline 2007 & 1.38 & 0.20 & 1.58 & 87.31 & 12.69 \\
\hline 2008 & 1.02 & 0.17 & 1.19 & 85.75 & 14.25 \\
\hline 2009 & 1.41 & 0.14 & 1.54 & 91.09 & 8.91 \\
\hline 2010 & 0.98 & 0.21 & 1.19 & 82.50 & 17.50 \\
\hline 2011 & 0.97 & 0.15 & 1.11 & 86.82 & 13.18 \\
\hline 2012 & 1.08 & 0.11 & 1.19 & 90.65 & 9.35 \\
\hline 2013 & 1.26 & 0.14 & 1.40 & 90.30 & 9.70 \\
\hline 2014 & 1.05 & 0.09 & 1.13 & 92.38 & 7.62 \\
\hline 2015 & 1.11 & 0.12 & 1.23 & 89.87 & 10.13 \\
\hline Mean & 2.05 & 0.48 & 2.54 & 83.54 & 16.46 \\
\hline Standard error & 0.16 & 0.11 & 0.23 & 2.06 & 2.06 \\
\hline
\end{tabular}

\section{DISCUSSION}

The descriptive and retrospective evaluation of the 30 years of infestation of the state of São Paulo by the vectors Ae. aegypti and Ae. albopictus showed nearly total territory coverage (99.69\%). With trajectories of initially antagonistic infestation and unequal larval abundances, Ae. aegypti has prevailed over Ae. albopictus. This performance may be related to behavioral differences and ecological aspects of each species ${ }^{1,13,14}$.

The onset of Ae. aegypti infestation in São Paulo was observed in the north-western municipalities of the state, taken as a result of the influence of infestations in the states of Mato Grosso do Sul and Paraná ${ }^{15}$. The first records of Ae. albopictus occurred in the southeast of the country, the most densely populated region of Brazil. Such information is important, since it is a space very close to important industrial, commercial and financial complexes of the state and the country. It is an area of important road axes and intense population flow, facilitators in the dissemination of these vectors ${ }^{16}$. The expansion of Ae. albopictus in the Vale do Paraíba region seen in the first 15 years can be ascribed to the absence of Ae. aegypti, since they are homologous species and therefore compete for the same ecological niche ${ }^{1,14}$. 
Surveillance and control actions of Ae. aegypti in developing countries, even in situations where resources for vector control have been appropriate, were often unsuccessful ${ }^{3,4,16}$. On the other hand, although Ae. albopictus was not a target species for these actions, it was constantly subject to their influence in Ae. Aegypti-infested areas, which may have caused selective pressure. The state of São Paulo has recorded its infestation since $1986^{5}$, first in areas with high population density and intense population flow, a factor that allowed its dispersion. However, another survey in São Paulo did not demonstrate any relationship between the pattern of geographic expansion and the demographic density of Ae. albopictus. The authors suggested the influence of other determining factors ${ }^{4}$.

The problem of an infestation is localized, and the compartmentalization of the region into municipalities, districts and even blocks favors the success of the control, since each sector or neighborhood of a city can present a reality in the different types of properties and breeding places attended by Ae. albopictus and Ae. aegypti, which constitute an area of risk for colonization ${ }^{4,17}$. Another study on the influence of different urban strata on the occupation of the city of São Paulo by Ae. aegypti showed that the urbanization gradient acts in the population expansion process of this vector, evidencing the influence of the environmental heterogeneity of each stratum in which the mosquito is found ${ }^{18}$.

The antagonistic trajectories mentioned previously underwent changes in time and space, to the extent that one of the species was established in cities first infested by the other. Thus, the dispersion advanced and culminated in the co-occurrence of Ae. Aegypti and Ae. albopictus in many municipalities (94\%) by 2015 . Other authors have already observed the association of these Stegomyia in several types of breeding places, mentioning that, although the relation of coexistence in urban and residential green areas is clear, there was a spatial separation of habitats, and suggested the occurrence of interspecific competition for oviposition sites $^{19,20}$. It is noteworthy that here co-occurrence was not a transitory situation, since it remains until the present day.

The dispersion of these vectors was a consequence of the increased global connection, and its distribution was influenced by several factors, among which temperature is indicated as important in the biology and behavior of these species ${ }^{7,15,21}$. Our study showed a clear and similar seasonal profile for these species, with presence in every month of the year, but with different larval densities. The highest abundances observed in the summer months coincided with the higher temperatures. Temperature seems to be one of the abiotic factors strictly related to the activities of Ae. aegypti. In a study carried out in the state of SP, the authors evidenced the effects of temperature on the geographic expansion of this species, while for Ae. albopictus these implications were not clear ${ }^{15}$.

In Southern Brazil, the preponderance of temperature in the longevity and fecundity of these species was confirmed, with a positive correlation between population increase and average monthly temperature ${ }^{22,23}$. This may be aggravated by the increase in the average temperature of the planet, which in turn should contribute to the expansion in Brazil of the distribution area of such other mosquito-borne viruses as oropouche, mayaro, rocio, and the Saint Louis encephalitis virus ${ }^{23}$.

In the present study, the increase of the highest average temperature ranges occurred in the northwest-southeast direction, coinciding with the geographical path of Ae. Aegypti infestation, which may have provided conditions for its expansion in the state. It is deduced that the temperature delayed but did not prevent the dispersion of this vector to the southeast region of the state, nor did it establish limits for the dissemination of the species studied.

Analyses of the annual minimum temperature series of SP from 1951 to 2006 showed elevation tendencies ${ }^{24}$. Similarly, the city of São Paulo has already presented changes in the historical series of temperature, indicating urbanization as a factor that affects the microclimate by creating islands of heat in the city ${ }^{8,25}$. 
The entomological surveillance in the state of São Paulo ${ }^{5}$, based on indicators, allowed the analysis of BI values routinely used to estimate the larval density of these mosquitoes. It was not our purpose here to discuss whether or not this larval index is a good indicator, presumably a limitation of the study, but rather to analyze it, because it has been used since 1985. Although BI mean values have varied over the years and across species, the percentage of containers with Ae. aegypti was 4.27 times as high as that of those containing Ae. albopictus.

Glasser et al. ${ }^{26}$, studying the immature forms of these species in Baixada Santista, a region of high population density in the south coast of the state of São Paulo, also observed that Ae. albopictus levels were much lower than those of Ae. aegypti, and that Ae. aegypti was present in most of these containers.

The highest percentage of containers with Ae. aegypti observed in our study allows to infer that its larval abundance is greater than that of Ae. albopictus, important information about the ecology of these species, since it provides evidence of an active competitive effect between these mosquitoes. This finding requires attention, given the usual sylvatic habits of this species, because their larval co-occurrence occurs in artificial breeding sites very common in areas of great human concentration ${ }^{20,26-29}$.

The patterns of relative abundance of the two species may vary widely. Differently from what is reported here, in southern Florida there was a decline in the abundance of Ae. aegypti after the invasion of Ae. albopictus ${ }^{28}$. It is understood that the success of a species may vary depending on the ecological, geographical, environmental and epidemiological circumstances.

The findings of our study revealed a state-wise predominance of Ae. Aegypti, but frequent presence of Ae. albopictus in densely urbanized areas. Although it is predominantly a peridomiciliar species, a possible selection of populations is reiterated based on a trend towards domiciliation ${ }^{9}$.

Although with lower densities, the presence of Ae. albopictus in these areas increases the risk of transmission of several arboviruses, which in turn reinforces the need to maintain and increase the monitoring of their populations as an essential part of entomological surveillance. These data are unprecedented and, therefore, constitute valuable information that contributes to a better understanding of the dynamics of arboviral transmission, besides providing elements for vector control.

\section{REFERENCES}

1. Oliveira AA, Maleck M. Ovitrampas para avaliação da presença de Aedes aegypti (Linnaeus) e Aedes albopictus (Skuse) no Município de Vassouras, Estado do Rio de Janeiro. EntomoBrasilis. 2014;7(1) https://doi.org/10.12741/ebrasilis.v7i1.369

2. Main BJ, Nicholson J, Winokur OC, Steiner C, Riemersma KK, Stuart J, et. al. Vector competence of Aedes aegypti, Culex tarsalis and Culex quinquefasciatus from California for Zika virus. PLoS Negl Trop Dis. 2018;12(6):e0006524. https://doi.org/10.1371/journal.pntd.0006524

3. Glasser CM, Gomes AC. Infestação do Estado de São Paulo por Aedes aegypti e Aedes albopictus. Rev Saude Publica. 2000;34(6):570-7. https://doi.org/10.1590/S0034-89102000000600002

4. Brito M, Marques GRAM, Marques CCA, Tubaki RM. Primeiro encontro de Aedes (Stegomyia) albopictus (Skuse) no Estado de São Paulo (Brasil). Rev Saude Publica. 1986;20(6):489. https://doi.org/10.1590/S0034-89101986000600011

5. São Paulo. Secretaria de Estado da Saúde, Superintendência de Controle de Endemias. Manual de vigilância entomológica de Aedes aegypti. São Paulo: SUCEN; 1997.

6. Rey JR, Lounibos P. Ecología de Aedes aegypti y Aedes albopictus en América y transmisión de enfermedades. Biomedica. 2015;35(2):177-85. https://doi.org/10.7705/biomedica.v35i2.2514

7. Kraemer MU, Sinka ME, Duda KA, Mylne AQ, Shearer FM, Barker CM, et al. The global distribution of the arbovirus vectors Aedes aegypti and Ae. albopictus. Elife. 2015;4:e08347. https://doi.org/10.7554/eLife.08347 
8. Ribeiro H, Pesquero CR, Coelho MSZS. Clima urbano e saúde: uma revisão sistematizada da literatura recente. Estud Avan. 2016;30(86):67-82. https://doi.org/10.1590/S0103-40142016.00100005

9. Rolim GS, Camargo MBP, Lima DG, Moraes JFL. Classificação climática de Köppen e de Thornthwaite e sua aplicabilidade na determinação de zonas agroclimáticas para o estado de São Paulo. Bragantia. 2007;66(4):711-20. https://doi.org/10.1590/S0006-87052007000400022

10. Fundação Sistema Estadual de Análise de Dados. Território e população do estado de São Paulo: SEADE; 2017 [cited 2017 Sep 27]. Available from: http://www.perfil.seade.gov.br/

11. Pereira M, Barbosa GL, Holcman MM, Gomes AHA, Ferreira ITRN, Wanderley DMV. Vigilância entomológica e controle vetorial da dengue no estado de São Paulo. Bol Epidemiol Paulista. 2015;12(135-136):11-16.

12. Instituto Nacional de Meteorologia. Precipitação total anual. Brasília, DF: INMET; 2017 [cited 2017 Sep 27]. Available from: http://www.inmet.gov.br/portal/index.php?r=clima/ page\&page=anomaliaTemp MediaAnual

13. Martins VP, Silveira DA, Ramalho IL, Florindo-G MI. Aedes albopictus no Brasil: aspectos ecológicos e riscos de transmissão da dengue. Entomotropica. 2013;28(2):75-86.

14. Glasser CM, Gomes AC. Clima e sobreposição da distribuição de Aedes aegypti e Aedes albopictus na infestação do Estado de São Paulo. Rev Saude Publica. 2002;36(2):166-72. https://doi.org/10.1590/S0034-89102002000200008

15. Instituto Brasileiro de Geografia e Estatística. Censo demográfico 2010: população: perfil dos municípios brasileiros. Brasília, DF:IBGE; 2017 [cited 2017 Sep 27]. Available from: http://www.ibge.gov.br/home/estatistica/economia/ perfilmunic/2015/

16. Donalísio MR, Glasser CM. Vigilância entomológica e controle de vetores do dengue. Rev Bras Epidemiol. 2002,5(3):259-79. https://doi.org/10.1590/S1415-790X2002000300005

17. Zara ALSA, Santos SM, Fernandes-Oliveira ES, Carvalho RG, Coelho GE. Estratégias de controle do Aedes aegypti: uma revisão. Epidemiol Serv Saude. 2016;25(2):391-404. https://doi.org/10.5123/s1679-49742016000200017

18. Wilke ABB, Wilk-da-Silva R, Marrelli MT. Microgeographic population structuring of Aedes aegypti (Diptera: Culicidae). PLoS One, 2017;12(9):e0185150. https://doi.org/10.1371/journal.pone.0185150

19. Passos RA, Marques GRAM, Voltolini JC, Condino MLF. Dominância de Aedes aegypti sobre Aedes albopictus no litoral sudeste do Brasil. Rev Saúde Publica. 2003;37(6):729-34. https://doi.org/10.1590/S0034-89102003000600007

20. Serpa LL, Marques GRM, Lima AP, Voltolini JC, Arduino MB, Barbosa GL, et al. Study of the distribution and abundance of the eggs of Aedes aegypti and Aedes albopictus according to the habitat and meteorological variables, municipality of São Sebastião, São Paulo State, Brazil. Parasit Vectors. 2013;6(1):321. https://doi.org/10.1186/1756-3305-6-321

21. Mordecai EA, Cohen JM, Evans MV, Gudapati P, Johnson LR, Lippi CA, et al. Detecting the impact of temperature on transmission of Zika, dengue and chikungunya using mechanistic models. PLoS Negl Trop Dis. 2017;11(4):e0005568. https://doi.org/10.1371/journal.pntd.0005568

22. Ajuz LC, Vestena LR. Influência da pluviosidade e temperatura ambiente na longevidade e fecundidade dos Aedes aegypti e Aedes albopictus na cidade de Guarapuava - PR e possibilidade de superinfestação. Rev Bras Geogr Med Saude. 2014;10(18):1-18.

23. Lorenz C, Azevedo TS, Virginio F, Aguiar BS, Chiaravalloti-Neto F, Suesdek L. Impact of environmental factors on neglected emerging arboviral diseases. PLoS Negl Trop Dis. 2017;11(9):e0005959. https://doi.org/10.1371/journal.pntd.0005959

24. Blain GC, Picoli MCA, Lulu J. Análises estatísticas das tendências de elevação nas séries anuais de temperatura mínima do ar no Estado de São Paulo. Bragantia. 2009;68(3):807-15. https://doi.org/10.1590/S0006-8705200900030003

25. Araujo RV, Albertini MR, Costa-da-Silva AL, Suesdek L, Franceschi NCS, Bastos NM, et al. São Paulo urban heat islands have a higher incidence of dengue than other urban areas. Braz J Infect Dis. 2015;19(2):146-55. https://doi.org/10.1016/j.bjid.2014.10.004

26. Glasser CM, Arduino MB, Barbosa GL, Ciaravolo RMC, Domingos MF, Oliveira CD, et al. Comportamento de formas imaturas de Aedes aegypti, no litoral do Estado de São Paulo. Rev Soc Bras Med Trop. 2011;44(3):349-55. https://doi.org/10.1590/S0037-86822011005000042 
27. Gomes AC, Forattini OP, Kakitani I, Marques GRAM, Marques CCA, Marucci D, et al. Microhabitats de Aedes albopictus (Skuse) na região do Vale do Paraíba, Estado de São Paulo, Brasil. Rev Saude Publica. 1992;26(2):108-18. https://doi.org/10.1590/S0034-89101992000200007

28. Vijayakumar K, Sudheesh Kumar TK, Nujum ZT, Umarul F, Kuriakose A. A study on container breeding mosquitoes with special reference to Aedes (Stegomyia) aegypti and Aedes albopictus in Thiruvananthapuram district, India. J Vector Borne Dis. 2014;51(1):27-32.

29. Ayllón T, Câmara DCP, Morone FC, Gonçalves LS, Barros FSM, Brasil P, et al. Dispersion and oviposition of Aedes albopictus in a Brazilian slum: initial evidence of Asian tiger mosquito domiciliation in urban environments. PLoS One. 2018;13(4):e0195014. https://doi.org/10.1371/journal.pone.0195014 interpretation, discussion and elaboration of the manuscript: DPFJ, GRAMM. Study planning, collection, analysis, interpretation of data and revision of the manuscript: LLNS. Data collection, analysis and interpretation and revision of the manuscript: GLB, MP, MMH, JCV.

Conflict of Interest: The authors declare no conflict of interest. 